\title{
The epistemic configuration of Hume's economic thought
}

Iara Vigo de Lima ${ }^{1}$

\begin{abstract}
Eugene Rotwein wrote in his 'Introduction' to David Hume Writings on Economics that works on Hume's economics have been primarily 'internal' studies. Beyond exploring Hume's insights for understanding economic phenomena, they have investigated either the relations between his philosophical thought and his economic analysis or emphasised their psychological and historical elements. The perspective in this paper is 'external', dealing with Hume's economic thought according to Michel Foucault's approach to history. Foucault sees the 'interiority' of thought as a doubling of what is outside of thought. It is in this sense that Foucault investigates Hume's context according to the concept of 'episteme', defining this as a set of relations that determines the ways of thinking. Foucault located Hume within the 'classical episteme' and I explore here his characterisation of that moment in order to understand the historical conditions of possibility of Hume's economic thinking
\end{abstract}

Keywords: Foucault; Hume; economic thinking.

1 Associate Professor at the Department of Economics of the Federal University of Parana, Brazil. E-mail: iaravigo@ufpr.br 


\title{
A Configuração Epistêmica do Pensamento Econômico de Hume
}

\begin{abstract}
Resumo: Eugene Rotwein escreveu em sua 'Introdução’ ao David Hume Writings on Economics que trabalhos sobre a economia de Hume têm sido primordialmente estudos 'internos'. Além de constituírem uma exploração das idéias de Hume sobre o entendimento dos fenômenos econômicos, tais estudos têm tanto investigado as relações entre o seu pensamento filosófico e suas análises econômicas, quanto enfatizado seus elementos psicológicos e históricos. A perspectiva deste artigo é 'externa', tratando do pensamento economic de Hume a partir da abordagem à história de Michel Foucault. Foucault via a 'interioridade' do pensamento como um duplo do que está fora dele. Foi neste sentido que Foucault investigou o context de Hume de acordo com a noção de 'episteme', definindo esta como um conjunto de relações que determinam as formas de pensar. Foucault localizou Hume dentro da 'episteme clássica' e eu exploro aqui sua caracterização de maneira a melhor entender as condições de possibilidade do pensamento econômico de Hume.
\end{abstract}

Palavras-chave: Foucault; Hume; pensamento econômico.

JEL: $\mathrm{B}_{3}, \mathrm{Z} 1$

\section{Introduction}

As Eugene Rotwein had already observed in the 'Introduction' of his David Hume Writings on Economics, works on the Hume's economic writings have been primarily 'internal'. They have been exploring either the relations between his philosophical thought and his economic analysis or emphasising their psychological and historical elements. And as the same author had also already pointed out, Hume was a thinker whose economic writings have a deep connection with his philosophical system (others who argue that are, for example, Wennerlind 2004; Schliesser 2004; Caffentzis 2001; Gruene and McClennen 2004). Rotwein remarked: 'Indeed, it is proper to regard his [Hume's] philosophical perspective as the most important internal factor shaping his appraisal of the different aspects of prevailing economic doctrine and his approach to the various issues of his period' (Rotwein 1955: xvii). One remarkable exception to this kind of approach is Sheila Dow's Hume and the Scottish Enlightenment: two cultures (Dow, 2009), in which she 
investigates the influences of the Gaelic epistemology on Hume and Scottish Enlightenment thought.

This paper follows Sheila Dow's approach, intending to be an 'external' study on Hume. It deals with Foucault's proposal of discerning the historical conditions of possibility of Hume's economic thought ${ }^{2}$. In his 1966 work The Order of Things (OT here after), Foucault developed an $\operatorname{archaeology}^{3}$ of the human sciences, which comprised also an archaeology of the political economy. Foucault wondered about the possibility of economics having historically followed a kind of 'well-defined regularity':

[I]f empirical knowledge, at a given time and in a given culture, did possess a well-defined regularity? If the very possibility of recording facts, of allowing oneself to be convinced by them, of distorting them in traditions or of making purely speculative use of them, if even this was not at the mercy of chance? If errors (and truths), the practice of old beliefs, including not only genuine discoveries, but also the most nanaïveotions, obeyed, at a given moment, the lanalysis of wealths of a certain code of knowledge? If, in short, the history of non-formal knowledge had itself a system? That was my initial hypothesis - the first risk I took. (OT: ix-x - emphasis in the original)

Foucault concluded that there was indeed a regularity, whose fundamental arrangement he denominated the 'episteme'. The 'episteme' is a structure ${ }^{4}$ that defines the conditions of possibility of at a given moment in time. It is either the one that expresses itself in a theory or the one that is implicit in practice. In this sense, the episteme is related to a certain perspective that determines the ways of theorising, of speaking, of reading, and so on. It is a 'structure' through which Foucault analysed what is said according to the relations of same-other, to the notion of language and representation, to the position of time (history) and space as the foreground and/or background of the subject-mattter, and the conception of man's finitude. Representation

2 The argument here is that I will follow Foucault's approach of Hume's context and, in this sense, from 'outside'. But it must be noticed that this idea concerns the 'folds' in the work of Foucault, where 'the "interiority" of thought is seen as a doubling of what is outside of thought', as Carrette (2000: 3) stressed.

3 Foucault employed the method of the 'archaeology' in his earlier works. He mentioned that he had borrowed the term 'archaeology' from Kant (Bernauer 1990: 45). In the whole of Foucault's work, 'archaeology' is indeed a part of a major tactic, the genealogy, procedure founded on Nietzsche's philosophy and widely used by Foucault, as he intended to rescue the emergence of certain historical events. It does not matter to the archaeologist of knowledge if an enunciate is true or false at the discursive level, but 'to see historically as the truth effects are produced inside the discourse that are not in themselves neither true nor false' (Foucault, 1984, p.60).

4 Although the use of the word 'structure' can be controversial because it relates Foucault to the movement of 'structuralism', I use it here not in the sense usually related to the movement, that is, a 'structure' that is given, determined, and it is the same in all ages. It has been argued that what differentiates Foucault from 'structuralism' is the fact that for him 'episteme' is no a priori, being indeed spatiotemporal. 
corresponds to the relations between subjects (through words - language) and objects (things).

Foucault used the concept of 'episteme' in $O T$ and discussed it in $A K$. In the $A K$, he defines episteme:

\begin{abstract}
By episteme, we mean, in fact, the total set of relations that unite, at a given period, the discursive practices that give rise to epistemological figures, sciences, and possibly formalized systems; the way in which, in each of these discursive formations, the transitions to epistemologization, scientificity, and formalization are situated and operate; the distribution of these thresholds, which may coincide, be subordinated to one another, or be separated by shifts in time; the lateral relations that may exist between epistemological figures or sciences in so far as they belong to neighbouring, but distinct, discursive practices. $(A K, 211)$
\end{abstract}

What was intriguing Foucault was the fact that some domains of knowledge have emerged almost at the same time. Particularly, the fact that the human sciences have arisen at the same period of history seemed to be very singular. He also believed that these sciences were only possible after the emergence of some empirical sciences: political economy, biology, and philology. However, in accordance with his discontinuist view of history, such domains of knowledge did not exist before the end of the $18^{\text {th }}$ century. He denominated the empirical fields of the classical episteme that gave rise to those sciences by analysis of wealth, natural history, and general grammar respectively.

Thus, $O T$ was built in accordance with his believe that these heterogeneous discursive practices had a common underlying configuration, which defined their internal procedures.

Foucault identified three historical periods marked by different epistemes: 'the age of resemblance' until the end of the 16th century (pre-classic); 'the age of representation', or classical episteme, which included the period from the beginnings of the 17th century to the second half of the 18th century; 'the age of history' or Modern Era from the end of the 18th century until the present time. He located David Hume's writings firmly within the classical episteme. Indeed, he stated that 'Hume has only become possible' (OT: 60) because of that configuration of thought. I investigate here Foucault's characterisation of that moment in order to understand the historical conditions of possibility of Hume's economic thinking. 


\section{Hume's epistemic context}

\subsection{General characterisation}

Hume's writings seemed clear in Foucault's consciousness when he discerned, or constructed if you prefer, the characterisation of the classical episteme.

Foucault describes that period as being 'the age of representation', whose expression was Descartes's system, in particular through the project of a general science of order - mathesis universalis ${ }^{5}$. Nevertheless, it is almost impossible to refer to it without referring, at least briefly, to the previous episteme, which Foucault called 'the age of resemblance' (up to the end of the $16^{\text {th }}$ century). Table 1 summarises Foucault's characterisation of the epistemes.

5 Here Foucault refers to the Descartes's dream of founding a universal science with the help of mathematics. Mathesis universalis was Descartes's designation to the science that would result from the application of a unified mathematical method. He enunciated this idea already in rule four of the Regulae: 'there must be a general science which explains all the points that can be raised concerning order and measure irrespective of the subject-matter, and that this science should be termed mathesis universalis...' (Descartes 1628: 19). The basic proposal was that knowledge should follow an itinerary/schedule from the ideas to the reality of things, being the first step to find just a unique certainty, a 'clear' and 'distinct' idea ('innate'), from which it would be possible to derive, by deduction, all knowledge. In his own philosophical project, this idea - axiom - was the Cogito. Therefore, the procedure should mirror itself on the sciences of mathematics. Descartes declared in the Discourse on Method: 'Those long chains composed of very simple and easy reasonings, which geometers customarily use to arrive at their most difficult demonstrations, had given me occasion to suppose that all the things which can fall under human knowledge are interconnected in the same way' (Descartes 1637: 120). 
TABLE 1. THE THREE EPISTEMES - MAIN CHARACTERISTICS: SAVOIR.

\begin{tabular}{c|c|c|c}
\hline \multirow{2}{*}{ Essential Elements } & \multicolumn{3}{|c}{ Episteme - Configuration of Knowledge } \\
\cline { 2 - 4 } & $\begin{array}{c}\text { Pre-Classical: } \\
\text { until the end of } \\
\text { the sixteenth } \\
\text { century }\end{array}$ & $\begin{array}{c}\text { Classical: Seven- } \\
\text { teenth and eigh- } \\
\text { teenth centuries }\end{array}$ & $\begin{array}{c}\text { Modern: from the } \\
\text { end of the eigh- } \\
\text { teenth century to } \\
\text { today }\end{array}$ \\
\hline $\begin{array}{c}\text { General character } \\
\text { Object of Knowl- } \\
\text { edge }\end{array}$ & $\begin{array}{c}\text { Age of Simili- } \\
\text { tude }\end{array}$ & $\begin{array}{c}\text { Age of Representa- } \\
\text { tion }\end{array}$ & Age of History \\
\hline $\begin{array}{c}\text { Mode of Knowledge } \\
\text { Things's Mode of } \\
\text { being }\end{array}$ & $\begin{array}{c}\text { Interpretation of } \\
\text { signs given by } \\
\text { God }\end{array}$ & $\begin{array}{c}\text { Nature } \\
\text { during the processo } \\
\text { f knowledge. The } \\
\text { system of signs is } \\
\text { constructed. }\end{array}$ & $\begin{array}{c}\text { Interpretation of } \\
\text { signs through man }\end{array}$ \\
\hline Main Procedure & Similitude & Order & Man \\
\hline Onalogy & $\begin{array}{c}\text { Analysis and order- } \\
\text { ing; tabulation }\end{array}$ & $\begin{array}{c}\text { Analogy and suc- } \\
\text { cession; not tabula- } \\
\text { tion, but a sequen- } \\
\text { tial connection (of } \\
\text { development) }\end{array}$ \\
\hline & $\begin{array}{c}\text { Time and } \\
\text { space had no } \\
\text { fundamental } \\
\text { meaning }\end{array}$ & $\begin{array}{c}\text { Spatial ordering } \\
\text { of things }\end{array}$ & Temporal \\
\hline
\end{tabular}

SOURCE: Authors own work based on Foucault's OT.

According to Foucault, until the end of that century, knowledge was a kind of 'mirror of nature'. Everything could be known through a set of connections of resemblances, which were printed on world by God. Resemblances were indeed God's signature. Man's task was to find them through detecting signs and finding analogies. For example, there were resemblances between the sky and the earth, relations between the composition of the sky and of the plants, and so on. There was nothing scattered in the world, things were linked one to the others per kinship and analogies. Divination and erudition, as Cousins and Hussain (1984: 34) affirm, 'are not different forms of knowledge,' because they are both forms of interpretation. Knowing is not analysing, but interpreting. Knowing was to realize the same, that is, to become fully aware of that which was 'both dispersed and related, therefore to be distinguished by kinds and to be collected together into identities' (Foucault's definition 
for 'the same' - OT: xxiv).

In the beginning of Hume's episteme, resemblance started being regarded with suspicion, as an occasion of error. Bacon and Descartes became possible, insofar as the former criticised resemblance through the description of idols, while, for the latter, resemblance was 'a confused mixture that must be analysed in terms of identity, difference, measurement and order' (OT: 52). Language is not only something given by God. Although 'the written word and things no longer resemble one another (...) language has not become entirely impotent' (OT: 48). That is, the separation between words and things had led to two main consequences: a) the gap was filled by representation; b) and a theory of language had become possible and necessary. Indeed, the act of knowing became the search for a well-constructed language. 'Knowledge (...) is like a language whose every word has been examined and every relation verified. To know is to speak correctly (...) The sciences are well-made languages, just as languages are sciences lying fallow' (OT: 87). Language provides the 'adequate signs for all representations' (ibid: 85). That is why 'language' could and should be studied, and a theory of language emerged (grammar). But language had a different conception from that which it was to have in our age. Indeed, it was not 'language' that was studied, but 'discourse' 6 understood as 'a sequence of verbal signs' (OT: 83). Discourse was studied as a verbal performance of language, as the first representation of thought. And until then, language is able to represent. There is no thought in terms of its limitations. 'Criticism' in the classical episteme just analyses language 'in terms of truth, precision, appropriateness, or expressive value' (OT: 80).

Knowing is not to try to connect things anymore, but 'to discriminate'. What was privileged was the space occupied by things in a sort of plan. To know was to organise them in a kind of table, in which identities and differences (the relations between the same and the other) should be identified. That was Descartes's general science of order. Order was the 'mode of being' of things (OT: 219). For example, in relation to the study of living beings (natural history), knowing consisted of describing them, ordering them, putting them in a table in accordance with their structure and character. This was done following four variables: form, number, arrangement, and magnitude. Living beings should be classified in kingdoms, species, families, genera, and so on.

Science broke off from history, because it had only led to obscurity, confusions and disagreements. Here, Foucault's statement does give rise to doubts when dealing with Hume. As it is well known, Hume had a great interest in history,

6 By 'discourse', Foucault does not mean what is built and operates through institutions, as he will understand it in later works. Discourse in the classical age was 'the spontaneous analysis of representation' (OT: 232). Foucault will use "discourse' as 'all the forms and categories of cultural life, including, apparently, his own efforts to submit this life to criticism' (White 1979: 82), as 'bodies of knowledge' and 'disciplines'. 'Disciplines' will be used in the meaning of scholarly disciplines, such as economics, science, medicine, etc., and 'institutions' of social control, such as prison, school, hospital, etc. (McHoul and Grace 1993: 26). It is only in the modern age that the emergence of man as a subject and object of knowledge led to 'discourse' in such meanings. 
which resulted from his empiricism. Indeed he was recognised for a long time by his History of England and he used historical data very frequently, including in his writings about economy, in order to support his theories.

However, the case is what Foucault means by 'history' here. He is saying that the 'history of knowledge' was neglected in the period. For example, Plato and Aristotle should not be studied anymore because they were something of the past that had only led to different opinions. Knowledge should restart everything, concentrating on the visibilities of things. Although it can be argued that Hume, following a tendency of the Scottish Enlightenment, studied many of the past thinkers, who did influence his thinking, he mainly used history as a source of data that inspired his investigations and supported his conclusions.

In the classical period, order and analysis replaced interpretation, while representation replaced resemblance. However, although resemblance was not the central category of knowledge anymore, it was kept as 'an indispensable border of knowledge' (OT: 67). Ordering would not be possible if it were not possible to group some of the perceptions according to resemblances among them. 'For no equality or relation of order can be established between two things unless their resemblance has at least occasioned their comparison' (OT: 67). And resemblance could only be established by imagination, given that ' $[w]$ ithout imagination, there would be no resemblance between things' (OT: 69). Resemblance and imagination formed the fundamental pair that allowed the discrimination of identities and differences. Foucault evokes Hume in order to stress the role of imagination for knowledge. Imagination was the operation of mind that allowed one to deal with a certain 'mechanics of the image in time' (OT: 69).

In the project of comparing and ordering things, the thought of classical episteme had essentially two kinds of problems. First, it had to deal with a ('interpenetrating') confused mixture of things. Second, although the order was confused, it could be glimpsed in the form of 'resemblances, vague similitudes' (OT: 69). Imagination was what allowed ordering by bringing to mind, even involuntarily, resonances that could form a table of comparisons. And so, the relation to time resullts from the fact that that jumbles of things involves that things occur or are presented to the mind linearly in time. However, when the table is being constructed, it is necessary to bring them together at the same moment in time. This is clearly a reference to Hume's conception. As Norton (1993) remarks, imagination for Hume is a faculty that allows 'compounding' impressions with the abstract 'ideas' of time and space. Hume argued that, although we have 'ideas' of space and time, we have no impression of space and time. Imagination was what allowed us, for Hume, to compound impressions in time and space, because it 'achieves what neither the senses nor reason can achieve', says Norton (idem: 9).

There was a fundamental change concerning the nature of the sign at the 
beginning of the $17^{\text {th }}$ century. Until then, God had created all things and put his signature on them. Since then, the sign was to be conceived as being constituted as such only during the process of knowledge. 'Now signs are knowledge, tools of analysis and means of representing order' (Cousins \& Hussain 1984: 33). According to Foucault, this fact and its consequences concerning the relation between a sign and that which it signifies must be analysed in accordance with three variables, which, again, clearly refer to Hume's philosophy. First, the certainty of the relation: sign became certain or probable. Because the signifying function of a sign only took place in the process of knowledge, it could be certain or a probable connection of meanings does not correspond necessarily to a relation of cause and effect, but only to an indication and to the relation of a sign to what it signifies. In this sense, the relation of causation can be questionable, as is clearly identified in the Hume's problem of causation. Second, the type of relation: a sign may belong to the whole that it denotes or can be separated from it. It is only through analysis that a sign can become apparent. Foucault states: 'because the mind analyses, the sign appears' (OT: 61), and, at the same time, a sign plays the role of instrument of analysis. After being established as such, a sign could be deployed to further impressions as it was in a grid. And third, the origin of the relation: a sign may be natural or conventional. Although this had already been in Plato, for example, the change was that an artificial sign could not keep its fidelity to a natural sign in order to be believable in knowledge. One more difference was in that, 'man-made signs' were thought to be superior. This idea of the creation of ideal conventional signs led, in that moment of history, to the ambition of creating a transparent language. It is in this sense that knowing was understood as the building of a taxonomy, given that knowledge was synonymous with 'well-constructed language'.

Therefore, at the level of the most elementary conditions of possibility, Foucault argues that Hume only became possible after this change in the organization of sign that occurred in the beginning of the $17^{\text {th }}$ century and that happened because of the breaking off from divinatio. The key features of Hume's system can be seen delineated in this Foucault's characterisation:

...the dissociation of the sign and resemblance in the early seventeenth century caused these new forms - probability, analysis, combination, and universal language system - to emerge, not as successive themes engendering one another or driving one another out, but as a single network of necessities. And it was this network that made possible the individuals we term Hobbes, Berkeley, Hume, or Condillac. (OT: 63)

And so, Foucault writes: 
The knowledge that divined, at random, signs that were absolute and older than itself has been replaced by a network of signs built up step by step in accordance with a knowledge of what is probable. Hume has become possible. (OT: 6o)

Insofar as knowledge can be uncertain, Hume introduced the case of probability. Russell (1946) explains Hume's understanding of probability:

\begin{abstract}
Hume does not mean by 'probability' the sort of knowledge contained in the mathematical theory of probability, such as that the chance of throwing double sixes with two dice is one thirty-sixth.(...). What Hume is concerned with is uncertain knowledge, such as is obtained from empirical data by inferences that are not demonstrative. This includes all our knowledge as to the future, and as to unobserved portions of the past and present. In fact, it includes everything except, on the one hand, direct observation, and, on the other, logic and mathematics (Russell 1946: 689)
\end{abstract}

\title{
2.2 The economic thought in the classical episteme
}

Despite the unity of knowledge projected in a mathesis universalis, there were two basic ways to pursue knowledge: mathesis or taxonomia. Mathesis was the science of calculable order; in other words, mathesis was applied when dealing with 'simple natures', aspects of reality susceptible to a quantitative, mathematical treatment. In the case of 'complex natures', that is, the empirical domains of knowledge, a taxonomia was pursued. And, unlike mathesis (algebra), taxonomia did not have a pre-established method, and so it had to create a system of signs (OT: 72) in order to apply it. 'What algebra is to mathesis, signs, and words in particular, are to taxonomia: a constitution and evident manifestation of the order of things' (OT: 203). The empirical domains of knowledge of general grammar, natural history and analysis of wealth pursued a taxonomia of their objects. Thus, the economic analysis was a taxonomia and Foucault argues that 'mercantilism', chronologically delimited by Scipion de Grammont and Nicolas Barbon (1637- ?1698), provided the necessary system of signs.

Hume's economic writings were inserted in that configuration of thought in which the basic signs were created by 'mercantilism'. Although Hume had great disagreements with 'mercantilists', and indeed aimed to expose their errors, he was within the same configuration of possibilities of thought. This 
was because, essentially, 'mercantilism' brought the thinking of price and money to the level of representations and established a system of signs in which wealth could be analysed into elements that permitted relations of equality or inequality and signify itself by means of those completely comparable elements of wealth called precious metals. At the same time, the idea was that all kinds of wealth in the world were related one to another in so far as they were part of a system of exchange. So, Foucault emphasises, in this system of signs 'there is no autonomous act of signification, but a simple and endless possibility of exchange' (OT: 179-80). Money, the sign of wealth, just had value in exchange. Therefore, economic thought happened inside a space of 'circular and surface causality' in which everything is composed of reciprocal relations between what was representing and what was represented. That is, there were explanations of how money could flow into a country or out of it, how prices rose or fell, how production grew, stagnated, or diminished. But all these 'movements' obeyed a kind of tabulated process, in which all values were able to represent one another. More precisely, prices increased when the representing elements (money) increased faster than the elements represented (commodities), production diminished when the instruments of representation (money) diminished in relation to the things to be represented (commodities), and so on.

'Wealth' was something that should be analysed and ordered in discourse. Indeed, 'wealth' was a 'general domain', 'the ground and object' of economy. It was 'the domain of needs' and Foucault declared that William Petty and David Ricardo marked its chronological frontiers (OT: 57). That is, Petty began the classical episteme and Ricardo started the modern age in economic thought. Hume's economic writings on money, trade, interest, population, and so on, had as the central motivation the process of creation of wealth. Eugene Rotwein, in the 'Introduction' of David Hume Writings on Economics, stated that 'the most basic level of Hume's economic thought takes the form of a natural history of the "rise and progress of commerce" in which he seeks to explain the development of economic activity through the impact of changing environmental forces on certain human passions' (Rotwein, 1955, p. xxxii - emphasis added). This statement from Rotwein is particularly interesting because it is reminiscent of the analogy to natural history that was underlined by Foucault.

As Foucault states, economic thought was focused on theories of value, money and prices. It started with the same problem of economic thinking during the previous episteme (up to the end of the $16^{\text {th }}$ century - 'the age of resemblance'): how to understand money and its relation to prices in exchange. Hume's economic analyses were dealing with the major questions of his period, as the titles of his essays attest: Of Money, Of Interest, Of Commerce, Of the Balance of Trade, and so on. He especially focussed on the impact of money in an economy and in the trade between/among nations. 
For Foucault, the fundamental distinction of Hume's economic context from the previous episteme was exactly in the conception of money. In the 'age of resemblance', the ability of money to measure price and to be the unity of exchanges rested upon its intrinsic value. Money was made of precious metals and they were wealth and a mark of it. The metals were useful to coinage because they themselves had a price. Money had value in its own right and, because of this, it was able to function as a sign in exchanges. Money was a sign because it has value by itself and by its resemblance with what it puts value on. Money was a sign signifying because of its resemblance to that which it signified. According to Foucault, this was the case until Davanzatti (1529-1606), who was the last figure of the 'age of resemblance'. However, in Hume's period, the value of money was not intrinsic to it. Its value will be just in its function as a sign, because it 'represents' the value of other things. For example, the usual criticism to 'mercantilism' for equating money with wealth is unfair, because it has been attributing to 'mercantilism' something that it really could not understand. For 'mercantilism', there was not the dilemma between 'money as a commodity or as sign'. Money was just a sign. Money was what permitted wealth to be represented. If such a sign did not exist, wealth 'would remain immobile, useless, and as it were silent' (OT: 177). Gold and silver, as universal signs, become scarce and unequally distributed commodities. 'Money cannot signify wealth without itself being wealth. But it becomes wealth because it is a sign' (OT: 177).

Wealth was not anymore the preciousness of metals, but it was constituted of everything that was object of need, utility, pleasure or rarity. Money became just a sign, a representation without own value. Money has value just as the representation of the wealth in exchange and circulation. Wealth increases because goods can circulate through money and then multiply.

In Of Money, Hume explored the relationship between the money supply and economic growth. As Wennerlind (2004) argues, Hume wanted to convince the legislator that money should be 'ignored', calling attention to the fact that wealth is created by the nation's people and industry. And there is no doubt that, unlike the thinkers of the $16^{\text {th }}$ century, Hume saw wealth as something distinct from the preciousness of metals, that is, he did not identify money and wealth. For him, money was only an instrument in exchange and, as Foucault characterises the classical episteme, Hume did understand 'money as a pledge'.

Foucault characterises the theory of money and trade as being a horizontal investigation of the process of exchange, i.e., it investigates the relations between/among things or kinds of wealth. Money is conceived as a pledge. Both upholders of 'money-as-sign' and of 'money-as-commodity' defined 'money as a pledge'. 'Money is a material memory, a self-duplicating representation, a deferred exchange' (OT: 181). Because money is a deferred exchange, it has to be a pledge. Because money was seen as a pledge, the ideas of money-as-sign 
and money-as-commodity both emerged. The difference between them was in that they considered to be a pledge: money-as-sign (Law and partisans) - money should be guaranteed by some merchandise exterior to monetary pledge (for example, land) or by the prince; money-as-commodity - money would be guaranteed as if it was coined with precious metals.

Indeed, Hume's conception of money does agree with this characterisation. In the very beginning of his Of Money: 'Money is not, properly speaking, one of the subjects of commerce; but only the instrument which men have agreed upon to facilitate the exchange of one commodity for another' (Hume 1970: 33). Hume did believe that money could be comprised of any material. He argued in favour of metallic substance because he believed that its scarcity provides a built-in discipline that facilitates the maintenance of confidence in the continued exhangeability of the currency' (idem: 33). He even used the term 'representation' to refer to the role of money. For example, in Of Money he stated: 'It is indeed evident, that money is nothing but the representation of labour and commodities, and serves only as a method of rating or estimating them' (idem: 37). Or in Of Interest: 'But as these metals [golden and silver] are considered chiefly as representations, there can no alteration arise, from their bulk or quantity, their weight or colour, either upon their real value or their interest' (idem: 48). Although the quantity theory of money had already emerged in the $16^{\text {th }}$ century, it had different meanings. For Davanzatti and Bodin ( $16^{\text {th }}$ century - 'age of resemblance'), there was an intrinsic devaluation of money because of the inflow of metals from America, causing an abundance of them in the Europe. However, at the end of the $17^{\text {th }}$ century, the quantity of money was thought of (by Locke, for example) as a proportion of the whole trade. Money began to be thought of as a sign, which was representative of wealth (OT: 183).

Moreover, according to Foucault, what articulated wealth was a system of exchange, that is, kinds of wealth were related one to another insofar as they all were part of a system of exchange. In this sense, value just existed within the process of exchange. There were basically two strands of thinking about value. Both were in the same 'theoretical segment' according to Foucault. The difference between them was in the way they looked at exchange. These strands were: the 'utilitarians' with their 'psychological theory' (Condillac \& Galiani \& Graslin); and the Physiocrats. The former analysed value as anterior to the exchange and as a primary condition without which the exchange could not take place. The latter analysed value in the act of exchange itself. For Physiocrats, exchange must exist in order for value and wealth to become possible. Quesnay and his disciples analysed wealth on the basis of what is given in exchange. They began their analyses with the thing itself which the exchage was designated in value, but which existed prior to the system of wealth (OT: 195). Value and wealth only exist if exchange is possible. And exchange creates value. The psychological school and the Physiocrats employed the same mode of analysis. The difference was the point of origin and 
the direction each one chose 'to traverse a network of necessity that remains identical in both' (OT: 191).

As in Hume's economic essays, Foucault argues that circulation became one of the fundamental categories of analysis. For Hobbes, for example, the circulation of money happened with duties and taxes; the state could redistribute it among private persons in the form of pensions, salaries, or remuneration for provisions bought by the state. It would stimulate the exchange of wealth, manufactures and agriculture. Just because of the space opened up by the relations between money and signs, wealth and representation, that it was possible to employ the metaphor of the circulation of the blood that had been recently developed.

For Foucault, there was a kind of circularity in economic thought, insofar as 'everything happens in terms of the reciprocal relations between what was representing and what was represented' (OT: 255), as I have already mentioned here. 'Value' was understood in terms of a system of exchange. The understanding of this statement becomes easier if we refer here to the modern episteme. In Foucault's view, the main difference in the modern age is that 'value' will be seen as a result of the productive power of labour. Ricardo was the first economist to present this conception. With him, labour started being the only source of 'value'. Therefore, there was no need for relating one value to another one in exchange. In this sense, 'value' was not to be a sign in a network of representations, as it was the case during the classical age.

In other words, Foucault is saying that in Hume's economic writings, 'value' was still a function of a network of representations, it was still a sign. This seems the case in Hume's economic analysis. Although Hume sometimes refers to 'labour', he did not make a clear relation between labour and value, as was the case in Smith and in the modern episteme. In OfCommerce, for example, Hume does state that: 'Every thing in the world is purchased by labour; and our passions are only causes of labour' (Hume 1970: 11). However, he did not develop a theory of value having labour as the source, keeping his analyses within a set of representations. 


\section{Why was Hume not a 'modern' thinker?}

\subsection{Modern episteme: general characterisation}

In the pre-classical episteme, to know was to interpret meanings given by God to the things. In the classical episteme, knowledge was possible through language. In the modern episteme, representation could no longer provide the foundation of knowledge by itself. Words are not signs representing things themselves, whatever they are. Words signify an interpretation of the things, as was the case before the end of the $16^{\text {th }}$ century, but with the great difference that words interpret meanings not given by God, but by man. In this sense, it is a self-representation, and because of that, there are always hidden meanings, unconscious elements, which have to be investigated, and will become the object of the emergent human sciences (psychology, sociology and the analysis of literature and myth). Signs from now on will have hidden meanings. Moreover, the foundation of knowledge will reside 'outside representation, beyond its immediate visibility, in a sort of behind-the-scenes world even deeper and denser than representation itself' (OT: 239). It may be said that, while in the pre-classical episteme 'creation' was the main figure underlying thought, this was replaced by 'the order of things' in the classical age, and in the modern episteme, 'man' plays this central role. According to Foucault, 'Man' emerged for knowledge. This involves thinking about both the conscious and unconscious in the figure of man, so human sciences emerged.

In contrast to the classical age that looked at the exterior of things, it is now necessary to look at the deepness of the objects. Things started being conceived as having an 'internal architecture'. In economics, 'labour' had to be thought of in terms of forms of production.

This shift in the way of thinking occurred during the years between 1775 and 1825, which can still be divided into two stages divided by $1795 / 1800$. Before 1775 , to know was to represent the visible - discriminating it, and unveiling its order. During the years from 1775 to $1795-1800$, one invisible element was added to the analysis in each one of those empirical domains: labour by Adam Smith, organic structure by Jussieu, and word inflection by Cordeoux and William Jones. Nevertheless, during this phase, knowing is still a representation: a representation of this invisible element. It was only after 1795/1800 that the representation really collapsed.

The definite shift (between 1795/1800 and 1825) was promoted by David Ricardo (1772-1823), Georges Cuvier (1769-1832), and Franz Bopp (1791-1867). Although they did not introduce the concepts of labour, organic structure and word inflection to their disciplines, they definitely removed them from 
the structure of the classical thought, transforming the discourse. This transformation of discourse reflected a change in the conception of the mode of being of labour, life and language. While in the classical thought they were conceived as having an underlying order, in the modern thinking they will be envisioned as a historical process.

Foucault employed the expression 'organic structures' not only to characterise the focus of biology, but also of political economy and philology in the modern era, because these positivities will be looking for understanding the internal relation between/among elements of their object in order to apprehend their functions. If one compares to the classical episteme, knowledge will not be to find identities and differences according to the visibility of things. Analogy and succession will be the 'organising principles'. Neither a taxonomia of non-quantitative orders nor a table will constitute knowledge. The space of order was shattered, says Foucault, and knowledge panorama will consist of: things having own organic structures, space that articulates them, time that produces them, and representation, in which individuals try to know (OT: 239-40).

In the first phase (1775-1795/1800), as Major-Poetzl (1983: 181) remarks, temporal concepts were added in the discourse, and so 'time' came for the front position, while 'space', which had been in the foreground in the classical tabular form of knowledge, was transferred to the background. Things 'escaped from the space of the table' (OT: 239) and cannot be represented only according to a taxonomia. Labour, life and language started being conceived as having a temporal constitution and that is what Foucault means by a 'historical dimension'. Differently from the analysis of wealth, political economy will not look for the source of value in things or in the exchange of things, but in the process of production.

Foucault denominates this new arrangement of thought by 'the age of history'. 'History' replaced 'order' as the main condition of possibility of knowledge. While 'reason' has been associated with the classical age, 'history' is related to the modern episteme. History will be the new 'mode of being' of things and became a new empirical science. Here, it may be possible to confuse the notions of history underlying Foucault's argument. History was not in the configuration of the classical episteme because to know was to begin everything again, looking at the visible structure of the subject matter. Therefore, Foucault was using 'history' in the sense of searching for the past of knowledge. In the modern episteme, 'history' became essential in the meaning of understanding things as having a temporal constitution (for example, in the economic thought, wealth results from a process of production that is temporal).

The succeeding course of time will be understood as something that is significant. This resulted from a new conception of sign that emerged with the 'decline' of representation. But Foucault emphasises that 'history' here is not a 
[C]ompilation of factual successions or sequences as they may have occurred; it is the fundamental mode of being of empiricities, upon the basis of which they are affirmed, posited, arranged, and distributed in the space of knowledge for the use of such disciplines or sciences as may arise. (OT: 219, emphasis added).

As well as order was the 'mode of being' of the things to knowledge in the classical thought, 'history' will be the 'mode of being' in the modern age:

The History is going to unfold the analogies that bring together one to the other different organizations in a temporal series. It is this history that increasingly will impose its laws to the production analysis, to the organising beings, after all to the linguistic groups. The History gives place to the analogical organizations as the Order opened its identity way and the successive differences. (OT: 299 - emphasis in the original)

That is, the unity of knowledge (savoir), the project of a general science of order (mathesis universalis), was broken. Between words and things, a number of unconscious elements were detected. 'Sciences' had now to think about this unconsciousness; man became an object and subject of knowledge and the human sciences emerged. In the new space of interpretation, the transcendental subject, who is the source of meaning, was separated from transcendental objects such as labour, life, and language.

A new ontological conception of beings emerged related to the idea of 'continuity'. In the classical episteme, there was a visible 'continuity' between/ among things, which allowed one to 'order' them. From the end of the $18^{\text {th }}$ century onwards, if there is this 'continuity', it should be searched for within things. This related things to their history.

Man found his finitude related to his power of knowing and his capacity for practically solving basic questions concerning life, labour and language. For the empirical sciences (biology, political economy and philology), he is a finite being because he is limited by the environment, by the forces of production, and by the linguistic heritage that have formed him (Gutting 1989: 199). He is subject to the laws of biology, of production and language. In economics, finitude is the realization of his limited conditions of making nature produce all that is necessary for his needs and desires. That is, 'scarcity' will have a different meaning from that which it had in the classical episteme. There, man should work in order to respond to his needs and desires. In the modern episteme, there will be a fundamental 'scarcity'. The nature is not fecund, as was believed. Indeed, it is miserly. This new conception led to the 'pessimistic' theory of Ricardo and to the principle of population of Malthus, for 
instance.

But, at the same time, man was to fight for surpassing his limitations. For instance, because he is responsible for representation, and in order to be able to act as the subject of knowledge, he must build a language, that is a formal language, which can provide him the tools to surpass his limitations. Therefore, language became an object of knowledge and some domains emerged or developed, such as analytic philosophy, formal logic and hermeneutics. Logic positivism became possible. The conditions of knowledge became a fundamental issue.

At the same time, man was found in an awkward situation, given that he was converted into subject and object of knowledge. The human sciences emerged to investigate man. But they do not investigate man as a living, labouring, and speaking being. This was the task ascribed to the positivities (biology, economics and philology). The human sciences will be concerned with man in what refers to the relations between his function as subject (who he is; what he can know) and the knowledge of him as an object.

While 'the other' was not manifest in the age of resemblance (being only implicit in the figure of antipathy), and was explicit in the analysis of differences in the classical episteme, it will be something 'produced' by the human sciences in the modern episteme. 'The other' in this new episteme refers to everything that is unconscious and that is responsible by the hidden meaning of the sign. For example, the 'alienation' in Marxism, insofar as it is a category created by the theory in order to refer to the 'disjuncture of man's existence and essence' that results from the relations of production based upon private property (idem: 56).

Man began to perform two functions in knowledge that are complementary and constitute what Foucault calls "historical a priori" or anthropologicalhumanist structure of the 19th Century thought. Firstly, man will be the object of the empirical sciences - life, labour, and language. Second, man is converted into philosophical fundament for the possibility of knowledge. It is this historical a priori that explains the arising of human sciences. Then, man is "a quite recent creature, which the demiurge of knowledge fabricated with its own hands less than two hundred years ago’ (OT: 308).

Whilst in the classical episteme man did not have a proper domain (OT: 308), in the modern episteme all that can be known will be deeply anthropological. Knowledge will be actually an 'analytic of finitude', which are man's efforts to think about his own conditions of possibility as a subject of knowledge ('fundamental finitude') and object of the empiricities ('founded finitude').

The place of the human sciences in knowledge results from a change in the conception of human nature. Indeed, these sciences only emerged in the modern era, Foucault argues, because they could not exist in the configuration of the 
classical episteme. In the classical age, the concept of 'nature' was underlying all the empirical knowledge in the sense that it was in the same level, so to speak, of representations. It was common to refer to others domains using the expression 'natural history"7. There was a natural order, and man was included in it. It was in this sense that Hume proposed the investigation of principles of human nature, as Broadie (1997), for example, declared:

When Hume spoke of a science of man, he was thinking of human beings as part of nature, and therefore most appropriately to be investigated by means proper to the study of nature. (Broadie 1997: 31)

Therefore, for Foucault, to consider Hume as a precursor of psychology reflects a misunderstanding of the conditions of possibility of thought. The human sciences are not studies about the human 'nature' in that sense. In the modern experience, the empirical contents of knowledge will be always related to the transcendental question of the conditions of knowledge. And there will be always the unthought, 'the Other', which is not in man or in things anymore (as it was the case in the classical way of thinking). In the modern era, the alterity is 'born, not of man, nor in man, but beside him and at the same time, in an identical newness, in an unavoidable duality' (OT: 326). The figure of man in the human sciences is always the 'double-entendre of all answers' (Cousins \& Hussain 1984: 61). The question in the modern age is no longer: 'How can experience of nature give rise to necessary judgements? [which was Hume's proposal, for example] But rather: How can man think what he does not think? (OT: 323). The human sciences link the knowledge of empirical to what man is and what he can know. They link man in his positivities (living, labouring, and speaking) to who he is and what he can know. They do not study what man is 'by nature'. They analyse what permits that man recognises himself as a living being, as a worker, and as a speaking subject. In Hume's episteme there was still a regularity, for instance, that allowed the association of impressions (resemblance) through imagination, which derived from that conception of human nature.

Particularly in reference to economics, the conception of 'nature' changed. There is now something 'exterior' to man, which is not part of his 'nature', or even if it is part of it, it is always 'unconscious', 'unknown'.

The most fundamental question conducting the investigations became: 'How can he [man] be that labour whose laws and demands are imposed upon him

7 For example, Eugene Rotwein stated in the 'Introduction' of David Hume Writings on Economics: ‘the most basic level of Hume's economic thought takes the form of a natural history of the "rise and progress of commerce" (Rotwein, 1955, p. xxxii - emphasis added). 
LIMA, I. V. The epistemic configuration of Hume's economic thought.

like some alien system?' (idem - emphasis in the original).

\subsection{Economic thought}

The table 2 summarises the epistemic configuration of economic thought in the three ages: pre-classical, classical and modern. 
TABLE 2. THE THREE EPISTEMES - MAIN CHARACTERISTICS: CONNAISSANCE OF ECONOMIC PHENOMENA

\begin{tabular}{|c|c|c|c|}
\hline & \multicolumn{3}{|c|}{ Episteme - Connaissance - Economic phenomena } \\
\hline & $\begin{array}{l}\text { Pre-classical - } \\
\text { until Davanzatti } \\
(1529-1606)\end{array}$ & $\begin{array}{l}\text { Classical - From Petty to } \\
\text { Adam Smith }\end{array}$ & $\begin{array}{l}\text { Modern - From } \\
\text { Ricardo until today } \\
\text { (?) }\end{array}$ \\
\hline $\begin{array}{l}\text { General do- } \\
\text { main }\end{array}$ & Money & Wealth & Production \\
\hline $\begin{array}{l}\text { Fundamental } \\
\text { category }\end{array}$ & $\begin{array}{l}\text { Money (value } \\
\text { and prices) }\end{array}$ & Exchange & Labour \\
\hline Mode of savoir & $\begin{array}{l}\text { Analogy: money } \\
\text { is a sign because } \\
\text { it is wealth }\end{array}$ & $\begin{array}{l}\text { Analysis and order: wealth } \\
\text { analysable in exchange }\end{array}$ & $\begin{array}{l}\text { History: Forms of } \\
\text { production differ ac- } \\
\text { cording to the pro- } \\
\text { ductive power of } \\
\text { labour. }\end{array}$ \\
\hline Money & $\begin{array}{l}\text { Has an intrinsic } \\
\text { value: precious } \\
\text { metals }\end{array}$ & Money is a pledge & Money is a pledge \\
\hline Value & Value=money & $\begin{array}{l}\text { Value is only created in } \\
\text { exchange; it is a function } \\
\text { of a network of represen- } \\
\text { tations }\end{array}$ & $\begin{array}{l}\text { Value results from } \\
\text { the productive power } \\
\text { of labour }\end{array}$ \\
\hline $\begin{array}{l}\text { Interpretation/ } \\
\text { Representation }\end{array}$ & Interpretation & $\begin{array}{l}\text { Network of representa- } \\
\text { tions, in which money, as } \\
\text { a sign of wealth, is what } \\
\text { represents. }\end{array}$ & $\begin{array}{l}\text { Interpretation: signs } \\
\text { created by Man }\end{array}$ \\
\hline $\begin{array}{l}\text { History: Space/ } \\
\text { time }\end{array}$ & - & $\begin{array}{l}\text { Space: wealth analysable } \\
\text { through exchange and } \\
\text { circulation. Circulation } \\
\text { is more important than } \\
\text { production. }\end{array}$ & $\begin{array}{l}\text { Time: process of } \\
\text { production involves } \\
\text { a historicity, which } \\
\text { is given by forms } \\
\text { of production. } \\
\text { Production became } \\
\text { more important than } \\
\text { circulation. }\end{array}$ \\
\hline Finitude & - & $\begin{array}{l}\text { Production of land can } \\
\text { provide the means to sat- } \\
\text { isfy man's desires and } \\
\text { needs. }\end{array}$ & 'Scarcity' \\
\hline
\end{tabular}

SOURCE: Authors own work based on Foucault's OT. 
The most general change in economics in the modern era resulted from the view of the 'organic structure' of the object, which resulted from the conception of a historicity (temporal series), and finitude. Whilst in the classical episteme, space was the main figure in knowledge, insofar as the table of visible identities and differences favoured spatial relationships, in the modern episteme time will become more important than space. The historicity of the object was revealed. Political economy will seek for the source of value in the process of production.

This is evident, argues Foucault, in the introduction of labour as the unit of value, which happened in Ricardo's theory. The notion of labour was already in Cantillon, Quesnay, and Condillac. And Adam Smith worked on the notion of labour as unity of value. However, they were still in the configuration of the classical episteme, given that they thought in terms of a network intervened by exchange. Smith related the concept of labour to wealth and saw the economic activity following a system of representations:

\begin{abstract}
(...) the quantity of labour indispensable for the production of a thing was equal to the quantity of labour that the thing, in return, could buy in the process of exchange', that is, 'all merchandise represented a certain labour, and all labour could represent a certain quantity of merchandise. (OT: 253)
\end{abstract}

For Foucault, Smith was still analysing 'wealth' according to the conditions of the classic episteme. The Scottish thinker understands 'wealth' as 'objects of need', which represent themselves in the movements and methods of exchange. Nevertheless, Smith was indeed in the transition to the new episteme, since in his writings, a thing was representable in units of work; labour was analysable into days of subsistence; value was still a sign. Value was defined on the basis of a total system of equivalences: commodities representing one another. Labour is a fixed and constant value exchangeable in all places and all times.

The distinction between value of use and value of exchange was previous to Smith. Cantillon had already pointed out the labour as a measurement of the value of exchange. The point is that Smith changed the relationship between labour and needs. Cantillon saw a man's labour as equal to the value of what he needed to maintain him and his family - food in the last resort. Therefore, it was necessity that defined the value of exchange. Needs defined the value of use and the exchange values. The relation between wealth and necessity marked all of classical thought. But, although Smith had not changed the function of labour, insofar as he saw it as a measure of exchange value, he understood labour as an absolute, irreducible, unit of measurement. Whilst in the classical episteme, labour was a measure for exchange 'relative' to objects of need, Smith understood labour as an absolute measure for exchange. 
In short, Smith employed the concept of labour to analyse exchangeable wealth; wealth is a representative element, but it does not represent objects of desire anymore; now, it represents labour. And, in this sense, Smith was in the transition between the two epistemes. In exchange, what is taken as the measure is not other objects and desires. It is labour. Within this duplication, Smith creates 'a principle of order that is irreducible to the analysis of representation: he unearths labour, that is, toil and time, the working-day that at once patterns and uses up man's life' (OT: 225). If one object can be exchanged by another, it is not because men have comparable desires, but because they are subject to time and to labour, which is not just dependent of his ability or self-interest. Man's labour is also subject to industrial progress, division of tasks, accumulation of capital, and division between productive and non-productive labour.

Therefore, says Foucault, Smith began a movement that surpasses the age of representation's borders. His reflection on wealth is not 'inside the analysis of representation' anymore, and it is distinct from 'the forms and laws of the decomposition of ideas'. It points to an antropology and open space for the emergence of political economy, whose object was not the exchange of wealth, but its production: forms of labour and capital. This was antropology, because Smith's system put in evidence man's essence.

However, it was only with Ricardo that economic thought entered the modern episteme, because he was the first to work on the history of labour ${ }^{8}$. Ricardo promoted the substitution of the 'circular and surface causality' of circulation by the conception of a 'linear, homogeneous series which is that of production' (OT: 255). Production has primacy over circulation.

The main difference Foucault identified between Smith and Ricardo is that, for the former, labour analysable into days of work could be used as a common unit of value for all merchandise. Commodities could be represented in terms of units of work. For Ricardo, a quantity of labour determines the value of a thing, not only because it can be representable in units of work, but also and more important because labour as a producing activity is 'the source of all value'. Value is not a sign anymore, it has become a product. Value has its origin in labour and it changes according the quantity of labour devoted to produce things; but it does not change according to an increase or decrease of wages, Foucault stresses mentioning Ricardo. After Ricardo, it is not trade and exchange that are the basis of the analysis of wealth. Labour is the basis, given that the exchange is based upon labour. Therefore, the theory of production was to precede that of circulation. This has three consequences:

1) A new form of causal series emerged. In the classical episteme, the economic thought had provided explanations of how money could

8 Major-Poetzl (1983: 154) argues that this was a provocative claim, because Marx could be considered the first. However, chronologically, Foucault can be right. 
flow into a country or out of it, how prices rose or fell, how production grew, stagnated, or diminished. From Ricardo on, labour was to be the causality without reference to anything else than something peculiar to it, i.e., the forms of production according to the degree of division of labour, the quantity of capital applied, etc. And when Ricardo promoted this dissociation, he made possible the articulation of economics upon history. Wealth became something that results from a historical process. Value is a result from certain conditions of production, which are determined by the quantities of labour applied to produce them, that is, there is a temporal sequence of production. Economic thought is not spatial analysis according to differences and identities anymore. In what seems to be one more provocative statement to Marxists, Foucault declares that:

Even before economic reflection was linked to the history of events or societies in an explicit discourse, the mode of being of economics had been penetrated, and probably for a long while, by historicity. (OT: 256)

2) Another change relates to the conception of scarcity. This was a decisive step for a theory of utility such as that introduced by the first marginalists at the end of the $19^{\text {th }}$ century. In the classical episteme, scarcity was related to needs, which could increase or take new forms and could be satisfied by the production of the land. Foucault argues that this was the view of both the mercantilists and physiocrats. For them, labour applied to land made it possible to overcome scarcity. From Ricardo onwards the scarcity became more explicit in the definition of the economic thought. Economics started having a relationship with anthropological implications. That is in Malthus's proposition of biological properties of human species that should be prevented by some remedy or constraint. Scarcity is also in Ricardo's theory, which addressed explicitly the question of population increase and the necessity of exploring less productive lands. Economics emerged as a necessary knowledge because of the fundamental situation of scarcity. Man must employ all possible means in order to make the economic activity to overcome the fundamental insufficiency of nature. For Foucault, the concept of homo economicus, 
as it emerged, is related to this fundamental scarcity.

3) The last main consequence is related to the evolution of economics. The 'rent of land' is not due to the fruitfulness of nature as it was conceived in the classical episteme and even in Smith's system. Nature was to be conceived by its avarice. Theories about the rise of population and the necessity of using progressively poorer lands emerged. Ricardo and Malthus, for example, have become possible, writes Foucault.

Therefore, according to Foucault, Hume was not thinking according to the conditions of possibility of the modern episteme. Hume's 'political economy' does not follow a conception of 'organic structure' or 'finitude of man' such as understood by Foucault. Hume's main concern was 'wealth' and not 'production'. Labour was not a fundamental notion to the understanding of economic activity, as was to be the case in Smith and, more precisely, in Ricardo. As Foucault argued, Hume's economics was still focused on analysing wealth in terms of a system of exchange of objects of desire and needs. Wealth was constituted by elements that could be replaced one by another through the mediation of the representative role of money and that which it signified. Hume's reflections on economy were inserted in this set of connections of representations. A system of exchange and circulation of money related wealth and money. He did not see wealth as being a result of different forms of production. Although Hume dealt with the development of industry, for example, and did refer to the role of labour for human economic action, his writings do not reflect a view of labour as being the determinant of value. In spite of his interest in history, he did not investigate economic facts according to a 'historicity', such as understood by Foucault in the modern episteme.

\section{Final remarks}

According to Foucault, Hume's economic thought followed the conditions of possibility determined by the classical episteme. More precisely, the elements of his thought only became possible because of the change in the nature of sign that happened in the beginning of the $17^{\text {th }}$ century. This led to the possibility of thinking of causation, uncertainty, probability, the role of resemblance and imagination, of man being determined 'by nature', and so on. Moreover, Hume's economic writings were possible because of the project of a science of order, which allowed analysing the elements of wealth according to equalities and differences. All the explanations concerning economic activity obeyed a 
kind of table in which all the 'movements' happened in relation to the role of money as a sign. That is, everything happened in terms of the reciprocal relations between what was representing and what was represented. Therefore, Hume was not a 'modern' economist, particularly because he was not thinking of economy in terms of 'organic structures'. The modern episteme only came into being in economics through Ricardo's theory, in which labour was to be the causality without reference to anything else than something peculiar to it, i.e., the forms of production according to the degree of division of labour, the quantity of capital applied, etc. Ricardo was who separated the notion of the creation of value from its representativity, making possible the articulation of economics upon history.

Foucault's characterisation of the conditions of possibility of Hume's thought leaves some questions that deserve being explored, especially concerned to the argument that each age is marked by only one episteme and the fact that Foucault does not explain the shifts between epistemes. This is particularly important in relation to Hume's cultural environment, as observed by Dow (2009).

\section{Bibliographical references}

BERNAUER, J. W. (1990). Michel Foucault's Force of Flight. Toward an Ethics for Thought. New Jersey and London: Humanities Press.

BROADIE, A. (ed.) (1997). The Scottish Enlightenment. An Anthology. Edinburgh: Canongate Classic.

CAFFENTZIS, C. G. (2001). 'Hume, Money, and Civilization; or, Why Was Hume a Metalist?'. Hume Studies, 27(2): 301-336.

COUSINS, M. \& HUSSAIN, A. (1984). Michel Foucault. London: Macmillan Education Ltd.

DESCARTES, R. (1628). 'Rules for the Direction of the Mind'. In COTTINGHAM, J. \& STOOTHOFF, R. \& MURDOCH D. (translation) (1985).

(1637). 'Discourse on the Method'. In COTTINGHAM, J. \& STOOTHOFF, R. \& MURDOCH D. (translation) (1985).

DOW, S. C. (2009). "Hume and the Scottish Enlightenment: two cultures". Revista de Economia (3): 7-20.

FOUCAULT, M. (1970) [1966]. OT. The Order of Things. An Archaeology of the Human Sciences. London: Tavistock Publications Limited.

(1972) [1969]. AK. Archaeology of Knwoledge. Translated by A. M. Sheridan Smith. London and New York: Routledge. 
(1984). "Truth and Power". In: RABINOW, Paul (ed.) The Foucault Reader. New York: Pantheon Books.

GRUENE, T. \& MCCLENNEN, E. F. (2004). "Hume's Framework for a Natural History of the Passions”. In SCHABAS M. \& WENNERLIND C. (ed.). Essays on David Hume's Political Economy. London: Routledge Press.

GUTTING, G. (1989). Michel Foucault's Archaeology of Scientific Reason. Cambridge, New York, Port Chester, Melbourne and Sydney: Cambridge University Press.

HUME, David (1970). David Hume: Writings in Economics. Edited and Introduced by Eugene Rotwein. Madison: University of Wisconsin Press.

LEARY, D. E. (1976). Essay Review: Michel Foucault, an Historian of the Sciences Humaines. Journal of the History of Behavioural Sciences (3): 286-93.

MAJOR-POETZL, P. (1983). Michel Foucault's Archaeology of Western Culture. Toward a New Science of History. Brighton: The Harvest Press Limited.

McHOUL, Alec \& GRACE, Wendy (1995). A Foucault Primer. Discourse, power and the subject. London: UCL Press.

NORTON, D. (1993). “An Introduction to Hume's thought”. In, NORTON, David Fate. (ed.) The Cambridge Companion to Hume. Cambridge: Cambridge University Press.

ROTWEIN, E. (ed.) (1955). David Hume. Writings on Economics. Edinburgh: Nelson.

RUSSELL, B. (1946). History of Western Philosophy and its Connection with Political and Social Circumstances from the Earliest Times to the Present Day. London: George Allen and Unwin Ltd.

SCHLIESSER, E. (2004). "Hume's missing shade of blue reconsidered from a Newtonian Perspective”. Journal of Scottish Philosophy 2: 164-175

SMITH, A. (1983). "Considerations Concerning the First Formation of Languages". In BRYCE, J.C. (ed.). SKINNER, A.S. (General Editor). Adam Smith. Lectures on Rhetoric and Belles Lettres. Oxford: Clarendon press.

STURROCK, J. (ed.) (1979). Structuralism and Since. From Lévi-Strauss to Derrida. Oxford, New York, Toronto and Melbourne: Oxford University Press.

WENNERLIND, C. (2004). “Artificial Virtue and Oil of Commerce: A Synthetic view of Hume's Idea of Money”. In SCHABAS, M. \& WENNERLIND, C. (ed.). Essays on David Hume's Political Economy. London: Routledge Press.

WHITE, H. (1979). ”Michel Foucault”. In STURROCK, John (ed.).

Recebido em: 10 de abril de 2010

Primeira resposta em: 30 de junho de 2010

Aceite em: 05 de julho de 2010 